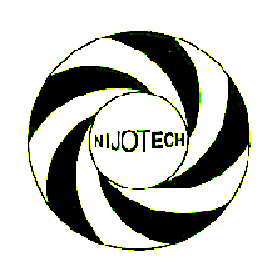

Nigerian Journal of Technology (NIJOTECH)

Vol. 33 No. 4, October 2014, pp. 537 - 546

Copyright(C) Faculty of Engineering,

University of Nigeria, Nsukka, ISSN: 111 15-8443

www.nijotech.com

http://dx.doi.org/10.4314/njt.v33i4.14

\title{
A FACTORIAL STUDY OF CONTRACTOR SELECTION CRITERIA IN OIL INDUSTRY
}

\author{
A. C. Igboanugo ${ }^{1}$ and 0. 0. Ogbeide ${ }^{2}$ \\ 1, 2 Production Engineering Department, University of Benin, Benin City, NiGERIA \\ E-mail addresses: ${ }^{1}$ dracigboanugo@yahoo.com,20sa_4me@yahoo.co.uk
}

\begin{abstract}
This paper was designed to investigate the various contractors' selection criteria and information sources on contractors so as to determine the common significant ones used for the selection of contractors within the oil industry in the Niger-Delta. The study employed a survey approach, using the Rensis Likert's attitudinal scale, to generate respondents data matrix that was analysed with principal component analysis (PCA), and which was facilitated by statistiXL software which clustered the fifty variables into fourteen fewer dimensions and the ten information variables into three dimensions. Our findings showed that the key selection criteria are acculturation, outsourcing management, duration of work, worker welfare and adherence to clients health. Others include safety and environment (HSE) programme, delivery capability, contractors responsiveness, quality assurance, innovation and drive to complete work and installation skill. Overall, this study has been successful in providing broad guide for contractors/vendors selection decisions for improved service delivery in the oil and gas industry.
\end{abstract}

Keywords: contractors, factor loading, varimax rotation, likert scale, earliest-start-time passion

\section{INTRODUCTION}

The oil and gas industry is a dominant contributor to the Nigerian economy and the on-going activities in this sector have been a major source of concern to stakeholders and the general public at large. It has been alleged at various fora that management of indigenous public and private companies in this industry do not follow due process in the allocation of some contracts regarding certain long-term and shortterm projects. The present situation in the country has shown that certain public procurements did not follow stipulated standard. A typical example is the issues surrounding the Minister of Petroleum Resources Jet Scandal which is reported in [1].

The process of selecting contractors for the execution of projects in the oil industry is an integrated one and it involves many certification and pre-evaluation activities. The Federal Government of Nigeria enacted a Public Procurement Act of 2007 in order to ensure that due process is followed in the selection of contractors generally. The nature of activities in the oil industry prompted the establishment of National Petroleum Investment Management Services (NAPIMS) which has the mandate to ensure that international standards and set criterion are strictly adhered to in the contracting process. Recent efforts to resolve the issues relating to contractors' selection criteria are reported in [2-5]. These papers did not identify underlying variables, or factors, that explain the pattern of correlations within the contractor selection criteria highlighted thereof.

This study focused on discussions regarding the establishment of the relative importance of contractors' selection criteria in the oil industry and the industry information sources on contractors. The influence that different tasks (routine services and capital projects) and different organisations (Exploration and Production Companies) have on the importance of contractor selection criteria is discussed. Hatush and Skitmore [5] identified five main processes as common factors in the contractor selection process for all types of procurement arrangements. These are project packaging, invitation, prequalification, short listing and bid evaluation. Also, Russel and Skibiniewski [6] defined bid evaluation as a decision-making process that involves the development and consideration of a wide range of necessary and sufficient decision criteria used to

* Corresponding author, Tel: +234-803-383-0934 
assess the contractors capabilities. Selecting the most suitable contractor for a construction project is a crucial decision for owners and project managers alike. In Egypt, the process of contractor selection for the public projects is regulated by Act 89/1998. The act was later reviewed. Relatedly in the United Kingdom, contractor selection are based on the lowest price philosophy. However, recent researchers show that there is a growing urge for a shift of emphasis from lowest-price wins to multi-criteria selection practices in the contractor selection process. In Nigeria, past performance, contractors experience, workmanship quality, tender sum, as well as plant and equipment are the most important criteria for contractors' prequalification/ bid evaluation. Tender evaluation is a very important and critical means through which the best evaluated tenderer is selected to undertake a project for a client so as to achieve best value for money. See for examples [8-17] As pointed out by Palaneeaswaran [18], contractor prequalification is generally preferred by clients to minimize risks and failures and to enhance the performance levels of selected contractors by means of established minimal capacities below which contractors will not be considered. Lam et al [19] proposed a fuzzy neural network (FNN) model, based on the fuzzy set and neural network theories for contractor pre-qualification and selection. The studies [21 - 23] examined the factor analysis to discern the inter-correlation among apparently many disparate variables that influence contractor selection process. This is made possible on account of the fact that factor analysis discern similarity in dissimilarity.

\section{RESEARCH METHOD}

The survey approach used incorporates the administration of questionnaires with five-point Rensis Likerts attitudinal scale. The response options were transformed into metric variables to aid statistical computation. This was used to develop a data matrix of fifty by sixty-three (50x63) based on the collation of the respondents scores. The metric quantities, collated as data matrix, served as input into the PCA. StatistiXL software was used to generate correlation matrix, factor matrix, parameter estimates, descriptive statistics, unrotated and Varimax rotated factors, scree plot and factor plot of the 50 variables studied. Factor loadings with acceptable values were highlighted in the factor matrix which yielded fourteen (14) factors. The factors were creatively labelled, interpreted and used as decision support for policy development. The unrotated factor space obtained could not lend itself to easy interpretation and so Varimax rotation became necessary. Factor loadings in the factor matrix below the threshold of 1 were discarded, (not considered for interpretation). It is important to observe that factorability of the correlation matrix was examined by visual inspection of the correlation matrix. It revealed substantial number of correlation coefficients greater than 0.30 , thus suggesting that the PCA is applicable.

The following assumptions about factor analysis based on postulations in [20-22] were made:

(a)Normality (shape of data distribution for individual matrix variable)

(b)Homoscedasticity (equal dispersion of variance across variables) and

(c)Linearity (columns of data matrix are seen as column vectors with linear characteristics)

The fifty variables obtained from literature are as depicted in Table 1.

Table 1: Fifty Variables of Contractors Selection Decision support

\begin{tabular}{cl}
\hline Item No & \multicolumn{1}{c}{ Scale Item } \\
\hline 1 & Competitive pricing \\
2 & Contractors Financial position \\
3 & Technical capability \\
4 & Quality Assurance \\
6 & Contractors inter personal relations \\
7 & Cognate Experience \\
8 & Equipment Dependability \\
9 & Paintenance culture \\
10 & Installation ability \\
11 & Past Failure Records \\
12 & Contractors Geographic Location \\
13 & Delivery capabilities \\
14 & Assurance of supply \\
15 & Sub-contractors Involvement \\
16 & Sub-contractors Skill \\
17 & Outsourcing Arrangement \\
18 & Strong Managerial capability \\
19 & Workers Welfare and safety records \\
20 & Health, security and safety procedure \\
21 & Contractors Responsiveness \\
22 & Project Management Skill \\
23 & Site Organization \\
24 & Operational Procedures \\
25 & Earliest Finish Time Passion \\
26 & Communication Management \\
27 & Team Playing \\
28 & Company's Litigation History \\
29 & Country of Origin \\
30 & Duration of work \\
31 & Standard of workmanship \\
32 & Genuine Organizational structure \\
33 & Host community Relations \\
\hline
\end{tabular}




\begin{tabular}{cl}
\hline Item No & \multicolumn{1}{c}{ Scale Item } \\
\hline 34 & Delegation of Authority \\
35 & Management Flexibility \\
36 & Category of Company \\
37 & Innovations \\
38 & After completion services \\
39 & Earliest start Time Passion \\
40 & Worker Motivation \\
41 & Financial Mobilization \\
42 & Client/Contractor Relationship \\
43 & Worker Permit Familiarity \\
44 & Insurance Coverage \\
45 & Technical Alternatives \\
46 & Work Order Adherence \\
47 & Effective Communication \\
48 & Employee-Management Relationship \\
49 & Trouble-Shooting Skill \\
50 & Environmental Management \\
\hline
\end{tabular}

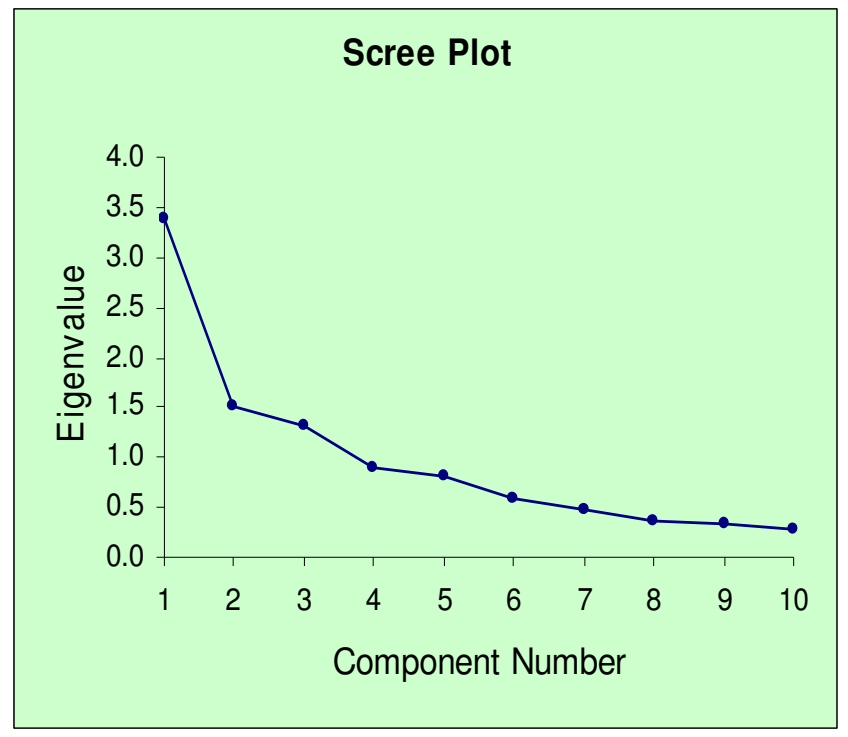

\section{Table 2: Ten Variable for Information Sources}

\begin{tabular}{ll}
\hline S/N & Variable \\
\hline 1 & Past Records \\
2 & Salesmen Involvement \\
3 & Visiting Contractors Plant \\
4 & Catalogues \\
5 & Purchasing Directories \\
6 & Contractors Financial Performance \\
7 & Information Sharing \\
8 & Advertisements \\
9 & Trade Fairs Exhibitions \\
10 & Pan-Departmental Commitment \\
\hline
\end{tabular}

\section{RESULTS}

The PCA analysis clustered the 50 contractor selection variables into 14 dimensions. Similarly, the 10 variables for information sources were reduced to mere three platoons. Varimax rotation made this reduction possible. However, the scree plot application suggests that the fourteen factors meet the requirements for factorability and interpretability. Appendix shows the unrotated factor matrix, Varimax rotated factor loading while Table 3 shows the explained variance (eigenvalue) see appendix. The scree plot showing the relationship between the eigenvalues and the variables is depicted in Figure 1. It is instructive to note that eigenvalue of unity (1) set the threshold for determining the candidacy of variables to be retained in the factor space.

Following is the first cluster of variables Tables 3 to 19 shows the factor platoons and their creative labelling

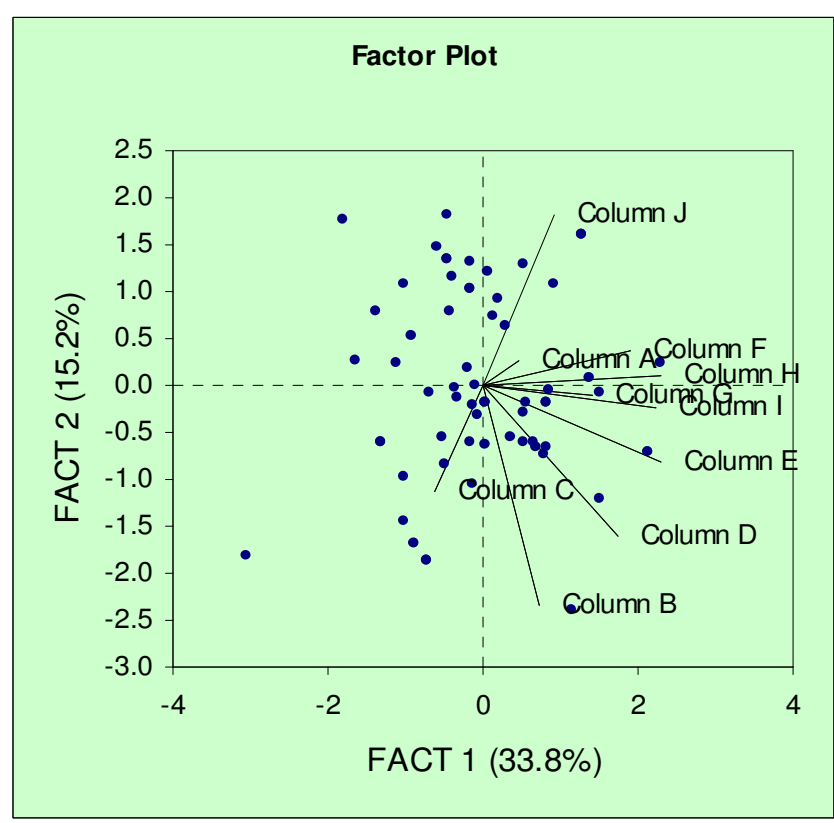

Figure 1: Scree Plot

Table 3: Cluster 1 (safety-critical consideration)

\begin{tabular}{|c|c|c|}
\hline $\begin{array}{l}\text { Variable } \\
\text { No. }\end{array}$ & Factor Loading & Variable Description \\
\hline 20 & 0.822 & $\begin{array}{l}\text { Health, security and } \\
\text { safety procedures }\end{array}$ \\
\hline 19 & 0.694 & $\begin{array}{l}\text { Workers Welfare and } \\
\text { safety Records }\end{array}$ \\
\hline
\end{tabular}

This is a duplex factor wielding meritorious and substantial loadings respectively. The duplex emphasizes the critical nature of safety consideration.

Table 4: Cluster 2 (Logistics)

\begin{tabular}{lll}
\hline $\begin{array}{c}\text { Variable } \\
\text { No. }\end{array}$ & \multicolumn{1}{c}{$\begin{array}{c}\text { Factor } \\
\text { Loading }\end{array}$} & \multicolumn{1}{c}{ Variable Description } \\
\hline 13 & -0.821 & Delivery Capabilities \\
14 & -0.782 & Assurance of Supply \\
10 & -0.677 & Installation Ability \\
\hline
\end{tabular}


The first two factors are meritorious while the third is substantial - they deal with logistics. All the three factors are negative.

\section{Table 5: Cluster 3 (Managerial Capability)}

\begin{tabular}{|c|c|c|}
\hline $\begin{array}{l}\text { Variable } \\
\text { No. }\end{array}$ & $\begin{array}{l}\text { Factor } \\
\text { Loading }\end{array}$ & Variable Description \\
\hline 25 & 0.799 & $\begin{array}{l}\text { Demonstration of ability to } \\
\text { complete work within budget }\end{array}$ \\
\hline 18 & 0.797 & Strong Managerial Capability \\
\hline 17 & 0.564 & $\begin{array}{l}\text { Methodology for managing Sub- } \\
\text { contractors }\end{array}$ \\
\hline
\end{tabular}

This study factor is crucial in the sense that management skill or managerial savvy plays important role in project management. A vendor with good management skill is needed in projects. Such vendors can identify hazards and risks that lurk in stillness only to spring up when it is least expected. However, with good management such risks can be planned for ahead of its occurrence. Again, such vendors can outsource jobs and coordinate them properly towards attainment of goals. Overall, the vendor will be able to deliver at the clients expected or scheduled time.

Table 6: Cluster 4 (Readiness)

\begin{tabular}{|c|c|c|}
\hline $\begin{array}{l}\text { Variable } \\
\text { No. } \\
\end{array}$ & $\begin{array}{l}\text { Factor } \\
\text { Loading }\end{array}$ & Variable Description \\
\hline 2 & -0.715 & $\begin{array}{l}\text { Financial position of the } \\
\text { Contractor }\end{array}$ \\
\hline 5 & -0.705 & $\begin{array}{l}\text { Contractor Inter- } \\
\text { personal relations }\end{array}$ \\
\hline 3 & -0.699 & Technical Capability \\
\hline 7 & -0.480 & Equipment dependability \\
\hline 8 & -0.415 & Maintenance Culture \\
\hline 9 & -0.408 & Personal Experience \\
\hline
\end{tabular}

This factor, creatively labelled readiness is a slender factor on account of the fact that all the variables under it are negative. Each of the variables contributes towards vendors' readiness to deliver. The relative importance of each factor is determined by the magnitude of its factor loading in the merit order.

Table 7: Cluster 5 (Pricing)

\begin{tabular}{lll}
\hline Variable No. & $\begin{array}{l}\text { Factor } \\
\text { Loading }\end{array}$ & Variable Description \\
\hline 1 & -0.673 & Competitive Pricing \\
\hline
\end{tabular}

This is a variable with substantial, negative factor loading. Vendors should quote competitively, otherwise through price fixing; they stand the risk of losing out and lose ground.

Table 8: Cluster 6 (Corporate Reputation)

\begin{tabular}{|c|c|c|}
\hline $\begin{array}{l}\text { Variable } \\
\text { No. }\end{array}$ & $\begin{array}{l}\text { Factor } \\
\text { Loading }\end{array}$ & Variable Description \\
\hline 11 & -0.824 & Past failure records \\
\hline 28 & -0.454 & $\begin{array}{l}\text { Company's Litigation } \\
\text { History }\end{array}$ \\
\hline
\end{tabular}

Again, this is a duplex factor wielding negative loadings - one substantial and the other middling

Table 9: Cluster 7 (Goodwill)

\begin{tabular}{ccl}
\hline $\begin{array}{l}\text { Variable } \\
\text { No. }\end{array}$ & $\begin{array}{l}\text { Factor } \\
\text { Loading }\end{array}$ & Variable Description \\
\hline 42 & 0.780 & $\begin{array}{l}\text { Clients/Contractor } \\
\text { Relationship } \\
\text { Advance payment prior } \\
\text { to work commencement }\end{array}$ \\
\hline
\end{tabular}

Further, another duplex factor is considered. Both are substantial and positive. Good client- vendor relations can enable a contractor obtain mobilization fund.

\begin{tabular}{ccl}
\multicolumn{3}{c}{ Table 10: Cluster 8 (Management by objective) } \\
\hline $\begin{array}{c}\text { Variable } \\
\text { No. }\end{array}$ & $\begin{array}{c}\text { Factor } \\
\text { Loading }\end{array}$ & \multicolumn{1}{l}{ Variable Description } \\
\hline 37 & 0.741 & Innovations \\
15 & 0.670 & $\begin{array}{l}\text { Sub-contractors } \\
\text { Involvement }\end{array}$ \\
35 & 0.623 & Management Flexibility \\
16 & 0.605 & Sub-contractors Skill \\
34 & 0.496 & Delegation of Authority \\
\hline
\end{tabular}

This is a quincucial factor (5-variable) creatively labelled authority delegation. The first has a substantial factor loading, the next three are near substantial while the last is a middling. This is akin to management by objectives in the sense that there is general flexibility on the part of the contractor which enables them to commit subcontractors through empowered delegation. Innovations are also introduced either by the vendor or the committed subcontractors.

Table 11: Cluster 9 (Performance)

\begin{tabular}{|c|c|c|}
\hline $\begin{array}{l}\text { Variable } \\
\text { No. }\end{array}$ & $\begin{array}{l}\text { Factor } \\
\text { Loading }\end{array}$ & Variable Description \\
\hline 38 & 0.731 & $\begin{array}{l}\text { After completion } \\
\text { services }\end{array}$ \\
\hline 30 & 0.693 & Duration of work \\
\hline 45 & 0.644 & $\begin{array}{l}\text { Technical } \\
\text { Alternatives }\end{array}$ \\
\hline
\end{tabular}

Vol. 33, No. 4, October 2014 
A triple factor is recorded in this regime: the first two are substantial while the last is a middling. All the three variables are positives. The variables deal with management of jobs during and after completion of jobs. It also considers good technical alternatives to adopt in the course of job execution.

Table 12: Cluster 10 (Corporate competence)

\begin{tabular}{|c|c|c|}
\hline $\begin{array}{l}\text { Variable } \\
\text { No. }\end{array}$ & $\begin{array}{l}\text { Factor } \\
\text { Loading }\end{array}$ & Variable Description \\
\hline 21 & 0.810 & $\begin{array}{l}\text { Contractors } \\
\text { Responsiveness }\end{array}$ \\
\hline 22 & 0.559 & Project Management Skill \\
\hline 49 & 0.477 & $\begin{array}{l}\text { Trouble-shooting Skill } \\
\text { Employee-management } \\
\text { Relationship }\end{array}$ \\
\hline
\end{tabular}

The next platoon of variables is a foursome factor creatively labelled corporate competence. It deals with issues relating to responsiveness in addressing defects arising from their performance.

\begin{tabular}{|c|c|c|}
\hline $\begin{array}{l}\text { Variable } \\
\text { No. }\end{array}$ & $\begin{array}{l}\text { Factor } \\
\text { Loading }\end{array}$ & Variable Description \\
\hline 39 & 0.745 & $\begin{array}{l}\text { Earliest-Start-Time } \\
\text { Passion }\end{array}$ \\
\hline 32 & 0.636 & $\begin{array}{l}\text { Genuine organizational } \\
\text { structure }\end{array}$ \\
\hline 31 & 0.561 & Standard of workmanship \\
\hline 23 & 0.553 & Site organization \\
\hline 40 & 0.521 & Worker motivation \\
\hline 33 & 0.495 & Host community Relations \\
\hline
\end{tabular}

A hexodic factor is considered here.The factor suggests that positive enthusiasm to commence work following an award is quite important.Again, the contractor must show quality workmanship,motivate staff and maintain cordial relationship with host community. All these will happen if a good organisational structure is put in place. It is only by so doing that corporate culture can resonate in all their undertakings.

\begin{tabular}{lll}
\multicolumn{3}{c}{ Table 14: Cluster 12 (Quality) } \\
\hline Variable No. & Factor Loading & Variable Description \\
\hline 4 & 0.809 & Quality Assurance \\
\hline
\end{tabular}

The principal component Analysis (PCA) Model adopted suggests that quality assurance is important in tendering. A Vendor that is well known for this attribute is always considered in contract jobs.
Table 15: Cluster 13 (Contiguity)

\begin{tabular}{ccl}
\hline $\begin{array}{c}\text { Variable } \\
\text { No. }\end{array}$ & $\begin{array}{c}\text { Factor } \\
\text { Loading }\end{array}$ & Variable Description \\
\hline 29 & 0.875 & $\begin{array}{l}\text { Country of origin } \\
\text { Contractors Geographic } \\
12\end{array}$ \\
0.524 & $\begin{array}{l}\text { Location } \\
\text { Effective } \\
\text { Communication }\end{array}$ \\
\hline
\end{tabular}

Here another triple factor is encountered. It emphasizes strategic integration to local tradition acculturation. This can be promoted through communication in local language. It tends to confer in the contractor some kind of provinciality.

Table 16: Cluster 14 (Knowledgeableness)

\begin{tabular}{ccl}
\hline $\begin{array}{c}\text { Variable } \\
\text { No. }\end{array}$ & $\begin{array}{c}\text { Factor } \\
\text { Loading }\end{array}$ & Variable Description \\
\hline 43 & 0.745 & Work Permit Familiarity \\
46 & 0.699 & Work Order Adherence \\
27 & 0.593 & Team Playing \\
26 & 0.562 & $\begin{array}{l}\text { Communication } \\
\text { Management }\end{array}$ \\
50 & 0.559 & Environmental \\
24 & 0.532 & Management \\
44 & 0.515 & Insurational Procedures \\
6 & 0.483 & Cognate Experience \\
36 & 0.439 & Category of Company \\
\hline
\end{tabular}

This is a novenary factor dealing with adherence to clients work culture and also playing along with the client.The loading are generally middling and are positive.

Information Sources

In this category, ten variables are reduced into three dimensions or factor

Table 17: Cluster 1 (Business directory)

\begin{tabular}{ccl}
\hline $\begin{array}{c}\text { Variable } \\
\text { No. }\end{array}$ & $\begin{array}{c}\text { Factor } \\
\text { Loading }\end{array}$ & Variable Description \\
\hline 5 & 0.760 & Purchasing Directories \\
8 & 0.755 & Advertisements \\
9 & 0.736 & Trade Fairs Exhibition \\
6 & 0.629 & Contractors Financial \\
4 & 0.577 & Performance \\
\hline
\end{tabular}

This dimension treats sources of obtaining information about the vendor. The sources are outlined in this factor, the most important being purchasing directories. 
Table 18: Cluster 2 (Personal Contact)

\begin{tabular}{ccl}
\hline $\begin{array}{c}\text { Variable } \\
\text { No. }\end{array}$ & $\begin{array}{c}\text { Factor } \\
\text { Loading }\end{array}$ & Variable Description \\
\hline 2 & -0.806 & $\begin{array}{l}\text { Salesmen } \\
\text { Involvement } \\
\text { Pan-Departmental } \\
\text { Commitment }\end{array}$ \\
\hline
\end{tabular}

This is another duplex factor comprising the salesmen involvement and pan- departmental commitment. The first variable is negatively and meritoriously loaded while the second is middling.

Table 19: Cluster 3 (Physical Inspection)

\begin{tabular}{ccl}
\hline $\begin{array}{c}\text { Variable } \\
\text { No. }\end{array}$ & $\begin{array}{c}\text { Factor } \\
\text { Loading }\end{array}$ & Variable Description \\
\hline 1 & 0.756 & Past Records \\
3 & 0.749 & Visiting Contractors \\
7 & 0.587 & Plant \\
\hline
\end{tabular}

In this regime, reliance upon contractors' records coupled with updating of such information through plant visit to contractors' factory is expedient. Moreover, information sharing with other companies can help vendors update their information.

\section{DISCUSSION}

The results of this study showed that corporate reputation is key to tender selection criteria of which history of vendor performance plays a major role in deciding which vendor to select. Usually, vendors with bad track records are blacklisted even before the real tender commences. This is the major reason why the PCA model used trumped it as the most offending variable with a negative factor loading of -0.824 . The implication is that vendor should strive towards doing their best in executing projects in order not to be in the black book of their client.

The study also identified delivery capability, adherence to clients HSE program, contractors responsiveness, quality assurance, acculturation, installation skill, worker welfare, outsourcing, innovations and drive to complete work early, Duration of work as the key variables that influence vendor selection. Contractors who possess the above traits would invariably be selected given that they will meet other criteria contained in the other platoons.

The research question addresses variation on contract selection criteria on routine services using the information sources. The study provided opportunity for the researcher to discover how to proffer solution and handle contractors selected through corrupt practices (bribery, kick-backs and connection to the powers that be).

Only $17.5 \%$ of the respondents claimed to have used multi-criteria decision analysis in selecting contractors. The awareness of this knowledge could be said to be relatively low in the construction industry. The management of oil companies are therefore enjoined to encourage and train their staff in the use of multi- criteria decision analysis model. One of such models is the analytical hierarchy process (AHP).

\section{CONCLUSION}

This study has been successful in providing broad guidelines for selection of contractors and vendors for service delivery in the oil and gas industry. The most important criteria for such selection have been highlighted. For managing contractors' selection based on corruption, the best bet is to make the contractor to source for funds in order to remain focused and implement the contract to a reasonable level prior to the release of milestones or stage payment. By so doing, pay-offs to benefactors are eliminated and contractors are discouraged from paying their way into the bidders list.

\section{ACKNOWLEDGEMENT}

The authors wish to acknowledge the contributions of Roman, Frederick Aigbehioria who carried out some preliminary investigations on the topic as part of his Master degree research project.

\section{REFERENCES}

[1] Ameh, J.(2014).www.punchng.com.accessed on March 26, 2014.

[2] Huang, X(2011). An analysis of the selection of project contractor in the construction management process. International Journal of Business and Management. Vol.6, No.3, pp.184-189

[3] Forghani, M. A and Izadi, L.(2013).Contractor Selection Based on Swot Analysis with Vikor and Topsis Methods in Fuzzy Environment. World Applied Sciences Journal. Vol.24, No.4, pp.540-549

[4] Ojo, A. E and Gbadebo, M. A.(2012).Critical Selection Crireria for Appropriate Procurement Strategy for Project Delivery, Nigeria Journal of Emerging Trends in Economics and Management Sciences. Vol.3, No.5, pp.422 - 428

[5] Chidolue, C. A, Nwanguaku A. I. and Okonkwo V. O. (2013), Rehabilitation of Onitsha-Enugu Dual Carriageway in Anambra State, Nigeria: Lessons 
Learned, Nigerian Journal of Technology, Vol. 32, No. 3 , pp. $393-402$.

[6] Cheng, E. W. L and Heng, L. (2004). Contractor Selection using the Analytic Network process, Construction Management and Economics. Vol.22, pp. $1021-1032$.

[7] Hatush, Z. and Skitmore, M. (1997). Criteria for contractor selection; Construction management and Economics, Vol. 15, pp.19-38.

[8] Russell, J. S and Skibniewski, M.J. (1988). Decision criteria in contractor prequalification; Journal of Management in Engineering, Vol.4, No.2, pp. 148 164.

[9] El- Sawah, H. M; Mokhtar, A. S. (2000). Analysis of Bid Evaluation Model According to the Egyptian Law 89/ 1998 and the International Practices, Engineering Research Journal, Helwan University, pp.1 - 17.

[10] Palaneeswaran, E; Ng, T; Kumaraswamy, M. (2006). Client Satisfaction and Quality Management Systems in Contractor Organizations. Building and Environment, Vol. 41, Issue 11, pp.1557 - 1570.

[11] Ang, G; Groosman,M; Scholten, N.P.M. (2005). Dutch performance-based approach to building regulations and public procurement; Business Research \& Information, vol.33, Issue 2, pp.107 - 119.

[12] Fong, P. S. and Choi, S. K. (2000). Final contractor selection using the analytical hierarchy process; Construction Management and Economics, Vol.18, pp. $547-557$.

[13] Ling, F. Y. Y. (2005). Global Factors Affecting MarginSize of Construction projects. Journal of construction Research, Vol.6, No.1, pp. 91 - 106
[14] Topcu, Y. I. (2004). A Decision Model Proposal For Construction Contractor Selection in Turkey. Building and Environment. Vol.39, Issue 4, pp. 469 - 481.

[15] Al-Harbi, K. M. A. S (2000). Final contractor selection using the analytical Hierarchy process. Construction Management \& Economics, vol.18, Issue 5, pp. 547 557.

[16] Andruskevicius, A. (2005). Evaluation of Contractors by using COPRAS - The Multiple Criteria Method. Technological and Economic Development of Economy. Vol.11, No.3, pp. 158 - 169.

[17] Ezeokonkwo J, C and Nwoji, C. U. Review of Trenchless Technologies, Success and their dependencies on Precise Geotechnical Information, Nigerian Journal of Technology, Vol. 33, No. 3, pp. 295 $-292$.

[18] Kvederyte, N; Zavadskas, E.K; Kaklauskas. (2000). A Multi- Criteria Analysis of Dwelling Life Cycle. Statyba (Civil Engineering), Vol. 6, No.3, pp. $179-192$

[19] Lam, K. C; Hu, T; Ng, S. T; Skitmore, M; Cheung, S. O. A. (2001). Fuzzy Neural Network Approach For Contractor Prequalification. Construction Management \& Economics, vol.19, Issue , pp.175 188.

[20] Cody, W. J. (1969). "Rational Chebyshev Approximations for the Error Function". Mathematics of Computation 23 (107): 631-638.

[21] Hamsici, O. C.; Martinez, Aleix M. (2007) "SphericalHomoscedastic Distributions: The Equivalency of Spherical and Normal Distributions in Classification", Journal of Machine Learning Research, 8, 1583-1623

[22] Higham, N. J. (2002). "Computing the nearest correlation matrix-a problem from finance". IMA Journal of Numerical Analysis22 (3): 329-343.

\section{APPENDIX}

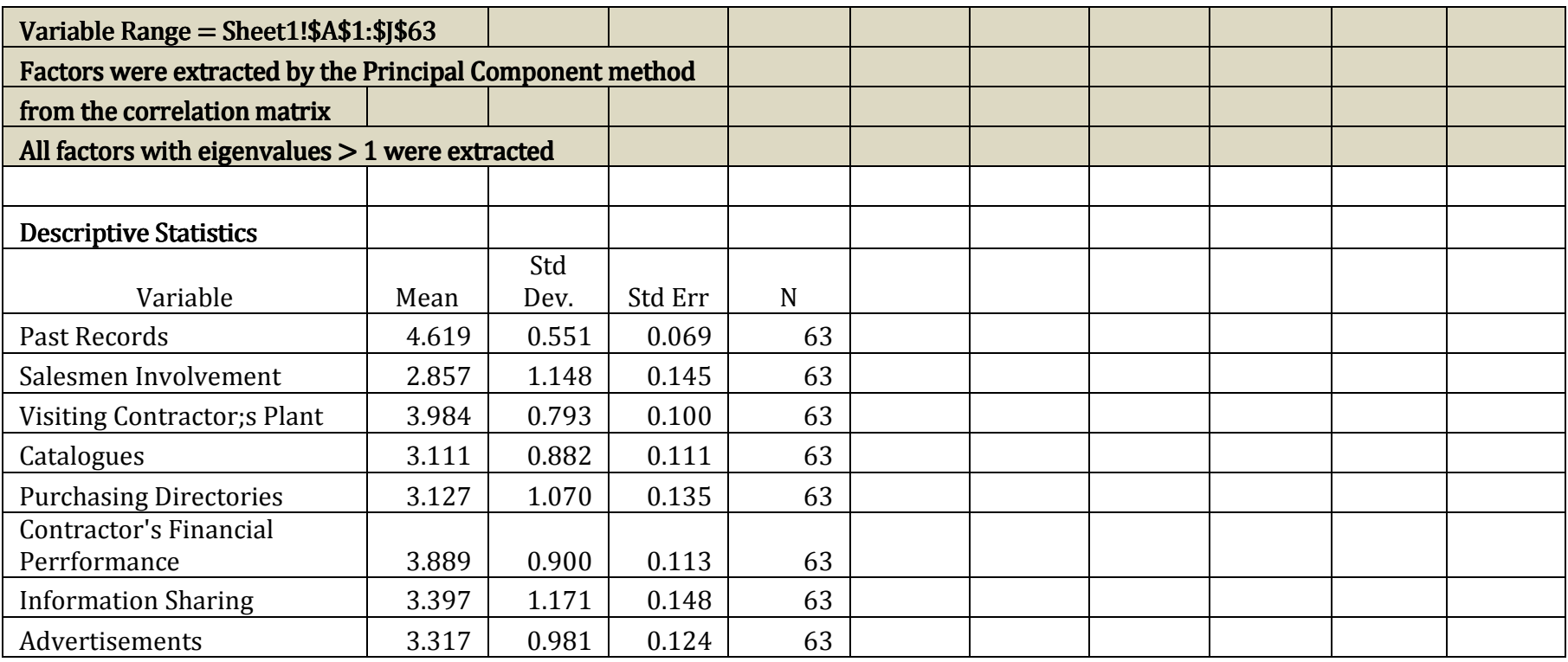




\begin{tabular}{|c|c|c|c|c|c|c|c|c|c|c|}
\hline Trade Fairs Exhibitions & 2.683 & 1.060 & 0.134 & 63 & & & & & & \\
\hline $\begin{array}{l}\text { Pan-Departmental } \\
\text { Commitment }\end{array}$ & 3.730 & 0.807 & 0.102 & 63 & & & & & & \\
\hline \multicolumn{11}{|l|}{ Correlation Matrix } \\
\hline & $\begin{array}{c}\text { Colum } \\
\text { n A }\end{array}$ & $\begin{array}{c}\text { Colum } \\
\text { n B }\end{array}$ & $\begin{array}{c}\text { Colum } \\
\text { n C }\end{array}$ & $\begin{array}{l}\text { Colum } \\
\text { n D }\end{array}$ & $\begin{array}{c}\text { Colum } \\
\text { n E }\end{array}$ & $\begin{array}{l}\text { Colum } \\
\text { n F }\end{array}$ & $\begin{array}{c}\text { Colum } \\
\text { n G }\end{array}$ & $\begin{array}{c}\text { Column } \\
\mathrm{H}\end{array}$ & $\begin{array}{c}\text { Colum } \\
\mathrm{n} \mathrm{I}\end{array}$ & $\begin{array}{c}\text { Colum } \\
\mathrm{n} \mathrm{J}\end{array}$ \\
\hline Past Records & 1.000 & 0.091 & 0.392 & 0.155 & 0.111 & 0.108 & 0.288 & 0.287 & 0.286 & 0.164 \\
\hline Salesmen Involvement & 0.091 & 1.000 & 0.405 & 0.558 & 0.370 & 0.031 & 0.307 & 0.170 & 0.267 & -0.147 \\
\hline Visiting Contractor;s Plant & 0.392 & 0.405 & 1.000 & 0.118 & 0.059 & 0.020 & 0.267 & -0.014 & -0.044 & -0.032 \\
\hline Catalogues & 0.155 & 0.558 & 0.118 & 1.000 & 0.446 & 0.239 & 0.394 & 0.313 & 0.504 & -0.003 \\
\hline Purchasing Directories & 0.111 & 0.370 & 0.059 & 0.446 & 1.000 & 0.450 & 0.294 & 0.560 & 0.420 & 0.059 \\
\hline $\begin{array}{l}\text { Contractor's Financial } \\
\text { Perrformance }\end{array}$ & 0.108 & 0.031 & 0.020 & 0.239 & 0.450 & 1.000 & 0.211 & 0.333 & 0.284 & 0.180 \\
\hline Information Sharing & 0.288 & 0.307 & 0.267 & 0.394 & 0.294 & 0.211 & 1.000 & 0.352 & 0.415 & 0.337 \\
\hline Advertisements & 0.287 & 0.170 & -0.014 & 0.313 & 0.560 & 0.333 & 0.352 & 1.000 & 0.502 & 0.171 \\
\hline Trade Fairs Exhibitions & 0.286 & 0.267 & -0.044 & 0.504 & 0.420 & 0.284 & 0.415 & 0.502 & 1.000 & 0.181 \\
\hline $\begin{array}{l}\text { Pan-Departmental } \\
\text { Commitment }\end{array}$ & 0.164 & -0.147 & -0.032 & -0.003 & 0.059 & 0.180 & 0.337 & 0.171 & 0.181 & 1.000 \\
\hline \multicolumn{11}{|l|}{$\begin{array}{l}\text { Explained Variance } \\
\text { (Eigenvalues) }\end{array}$} \\
\hline Value & $\begin{array}{c}\text { Factor } \\
1\end{array}$ & $\begin{array}{l}\text { Factor } \\
2\end{array}$ & $\begin{array}{c}\text { Factor } \\
3\end{array}$ & $\begin{array}{c}\text { Factor } \\
4\end{array}$ & $\begin{array}{l}\text { Factor } \\
5\end{array}$ & $\begin{array}{c}\text { Factor } \\
6\end{array}$ & $\begin{array}{c}\text { Factor } \\
7\end{array}$ & $\begin{array}{l}\text { Factor } \\
8\end{array}$ & $\begin{array}{l}\text { Factor } \\
9\end{array}$ & $\begin{array}{c}\text { Factor } \\
10\end{array}$ \\
\hline Eigenvalue & 3.382 & 1.522 & 1.327 & 0.891 & 0.811 & 0.598 & 0.479 & 0.377 & 0.330 & 0.282 \\
\hline$\%$ of Var. & 33.818 & 15.224 & 13.267 & 8.906 & 8.108 & 5.985 & 4.794 & 3.771 & 3.304 & 2.823 \\
\hline Cum. \% & 33.818 & 49.042 & 62.309 & 71.215 & 79.323 & 85.308 & 90.102 & 93.874 & 97.177 & $\begin{array}{r}100.00 \\
0 \\
\end{array}$ \\
\hline \multicolumn{11}{|l|}{ Communalities } \\
\hline & $\begin{array}{c}\text { Variabl } \\
\mathrm{e}\end{array}$ & & & & & & & & & \\
\hline Past Records & 0.601 & & & & & & & & & \\
\hline Salesmen Involvement & 0.780 & & & & & & & & & \\
\hline Visiting Contractor;s Plant & 0.756 & & & & & & & & & \\
\hline Catalogues & 0.659 & & & & & & & & & \\
\hline Purchasing Directories & 0.660 & & & & & & & & & \\
\hline $\begin{array}{l}\text { Contractor's Financial } \\
\text { Perrformance }\end{array}$ & 0.411 & & & & & & & & & \\
\hline Information Sharing & 0.565 & & & & & & & & & \\
\hline Advertisements & 0.592 & & & & & & & & & \\
\hline Trade Fairs Exhibitions & 0.583 & & & & & & & & & \\
\hline $\begin{array}{l}\text { Pan-Departmental } \\
\text { Commitment }\end{array}$ & 0.624 & & & & & & & & & \\
\hline \multicolumn{11}{|l|}{ Unrotated Factor Loadings } \\
\hline Variable & $\begin{array}{c}\text { Factor } \\
1\end{array}$ & $\begin{array}{l}\text { Factor } \\
2\end{array}$ & $\begin{array}{c}\text { Factor } \\
3\end{array}$ & & & & & & & \\
\hline Past Records & 0.439 & -0.177 & 0.614 & & & & & & & \\
\hline Salesmen Involvement & 0.552 & -0.623 & -0.295 & & & & & & & \\
\hline Visiting Contractor;s Plant & 0.278 & -0.713 & 0.412 & & & & & & & \\
\hline Catalogues & 0.713 & -0.209 & -0.327 & & & & & & & \\
\hline Purchasing Directories & 0.722 & 0.150 & -0.341 & & & & & & & \\
\hline $\begin{array}{l}\text { Contractor's Financial } \\
\text { Perrformance }\end{array}$ & 0.500 & 0.396 & -0.068 & & & & & & & \\
\hline Information Sharing & 0.671 & -0.052 & 0.334 & & & & & & & \\
\hline Advertisements & 0.695 & 0.328 & -0.038 & & & & & & & \\
\hline Trade Fairs Exhibitions & 0.730 & 0.213 & -0.070 & & & & & & & \\
\hline Pan-Departmental & 0.248 & 0.465 & 0.589 & & & & & & & \\
\hline
\end{tabular}




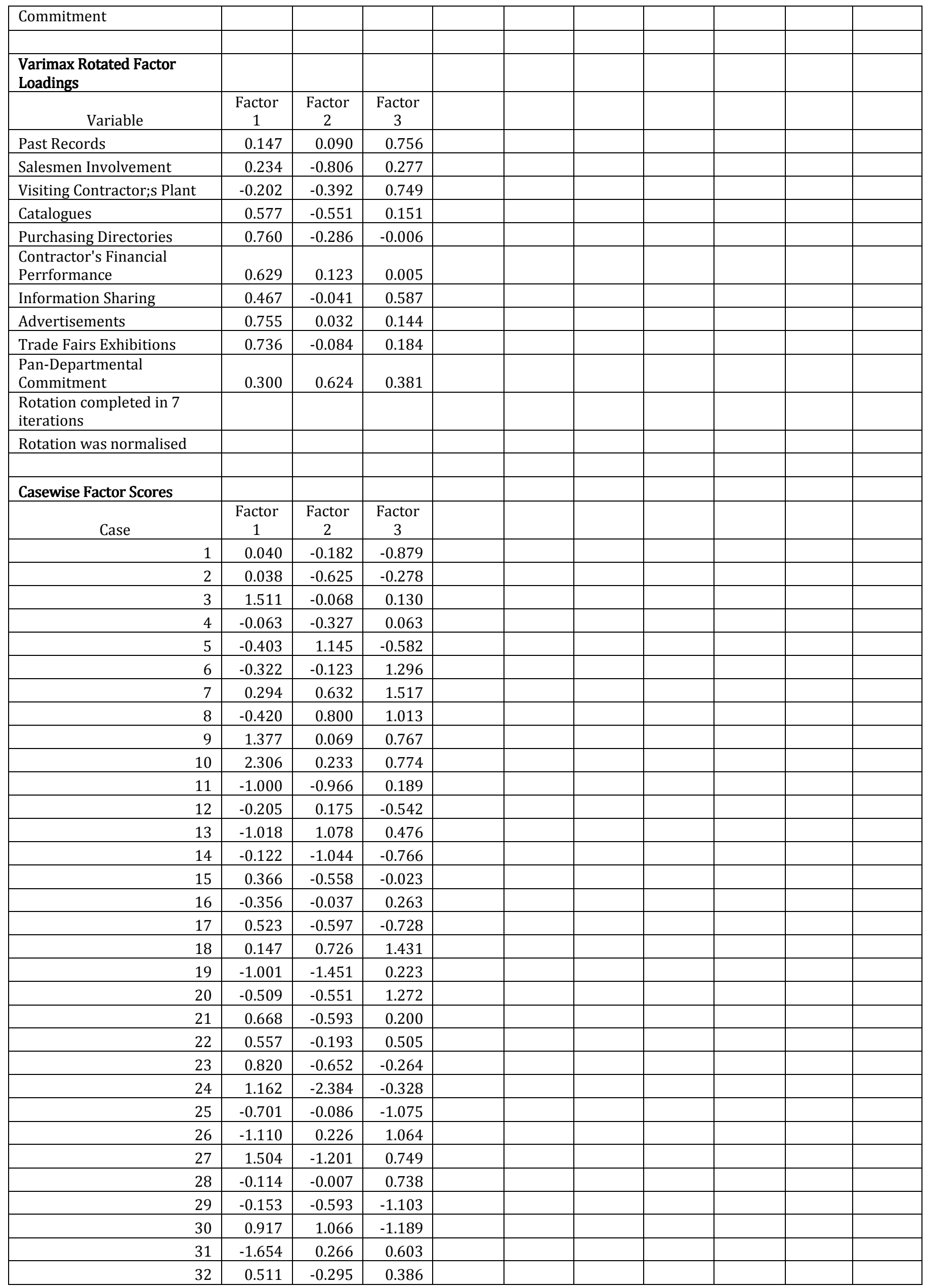


A FACTORIAL STUDY OF CONTRACTOR SELECTION CRITERIA IN OIL INDUSTRY

A. C. Igboanugo \& 0.0 . Ogbeide

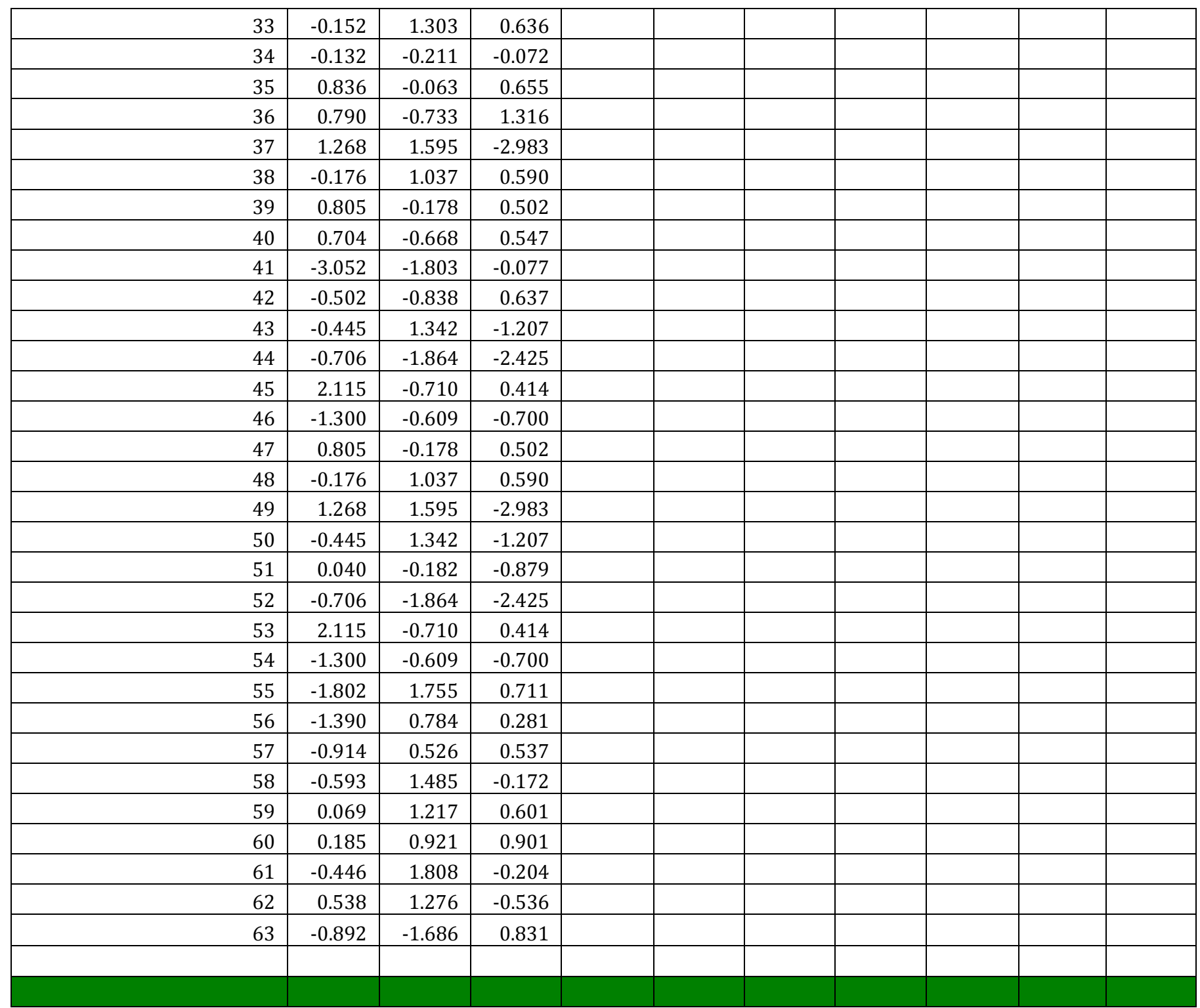

